\title{
Smart City. "Smart" Infrastructure, Networks and Communications
}

\author{
Mikhail B. Dvinsky*, Ivan A. Drobyshev, \\ Natalia V. Nepomnyaschaya \\ and Tatiana V. Pavluchenko \\ Siberian Federal University \\ 79 Svobodny, Krasnoyarsk, 660041, Russia
}

Received 12.10.2017, received in revised form 22.10.2017, accepted 16.11.2017

The modern development of a city with the population exceeding one million is becoming increasingly impossible in the "classical" way. The key problem of any dynamically growing megalopolis is the backlog of infrastructure development or the inability of the latter to effectively meet the needs of all the elements of the city. At the same time, the city does not have an opportunity to provide new areas of land resources for its development. Different cities and countries find their solutions to this issue, and recently the concept of "smart city" has been gaining popularity. Exemplified by the city of Krasnoyarsk, the article examines the obligatory requirements for infrastructure (mainly transport infrastructure) within the concept of "smart". The current trends in the city's development and comparison of the expected results of the "smart city" concept are defined, the directions of the city infrastructure development to ensure the possibility of transition to the development within the "smart" concept are proposed.

The research is carried out within the framework of the grant "Methodical Approaches to the Formation of the Concept of the Smart City Project within the Framework of the Development Trends for Digital Economy" with the financial support of the Krasnoyarsk Regional Fund for Support of Scientific and Technical Activity.

Keywords: smart city, infrastructure, transport, smart networks.

DOI: 10.17516/1997-1370-0187.

Research area: economics.

\section{Modern infrastructure needs of cities and the need to apply the concept of "smart"}

The modern city makes high demands on the population mobility as well as provision of connection, information and communications infrastructure. There is an interesting statement that the city cannot develop faster than the opportunities of the infrastructure industries that ensure its mobility: transport and communications. The concept of "step-by-step" accessibility, which was actively used in the Soviet era, and which made it possible to reduce the consumption of transport and communications services, nowadays is increasingly becoming unsuitable for a number of reasons: the increased

(C) Siberian Federal University. All rights reserved

* Corresponding author E-mail address: mike11.80@mail.ru 
differentiation of employment and recreation places, people's and public associations demands in meeting the needs of a higher level through communication and presence and changing the image and standards of life.

Meeting the aforementioned modern demands becomes impossible only in a "physical" way, as is often done till now. For example, there is a heavy traffic on one of the intersections of transport corridors and the construction of a multi-level interchange might by a solution. This step solves or alleviates the problem for a relatively short period of time. Further, the city has to start its other traffic flows in this direction and construction actively develops the adjacent territory with good transport accessibility. As a result, the load on this infrastructure object, which was not planned at the stage of its design, increases. The situation returns to the starting point.

It is also important to understand a fundamental limitation - the city has a clearly limited territory, which does not allow applying the "physical" method of solving infrastructure development problems indefinitely. In the past century, cities actively expanded their "physical" capabilities through technologies: the construction of underground transport (metro), increase in the speed of data transfer by creating additional information centers, etc. But each time a new stage of technological development becomes more and more expensive. As a consequence, only the most economically developed cities with the population exceeding one million can afford it. For instance, experts estimate the construction of underground in the city of Krasnoyarsk in more than 200 billion rubles.

A distinctive feature of the "smart" concept is its systemic nature: the construction of not a separate transport interchange in a given location, but the increase in the efficiency of communications between the traffic flow participants in order to achieve the same result reducing the total travel time for all the traffic participants or providing greater capacity for the same time interval.

Today within the frames of "smart" concept in the field of passenger traffic the preference is given to public high-speed transport. Most scientists and practitioners in the world do not see the possibility in the near future to effectively meet the needs of society for mobility using private vehicles.

\section{Development of transport infrastructure and street and road network within the "smart" concept}

The necessity and expediency of the Krasnoyarsk transport system development, based on the concept of "smart", is determined by the following problems and challenges:

- Steady decrease in passengers transportation by public transport in favor of the growth of transportation by private vehicles. Passenger turnover of automobile transport in 2016 was 1202.9 million people per km (92.4\% compared to the level of the previous year), cargo turnover - 333.5 million tons per $\mathrm{km}(68.9 \%$ compared to the previous year).

- Changing the direction of traffic flows towards the new centers of settlement, services and trade.

- Inconsistency of the city's transport system to the current needs of population (daily pendular migration) and cargo movements.

- The increase in the load on the transport network due to the growing automobilization of the population. The total length of the street and road network of Krasnoyarsk is $1174.9 \mathrm{~km}$ of roads with hard surface. As of the end of 2016, $68.9 \%$ of public roads of local significance do not meet the established regulatory requirements.

- Institutional restrictions, including those in the field of private homeowners' rights, 
hampering the development of the city with low-rise buildings.

In general, the projected growth in the population of Krasnoyarsk, the development of agglomeration processes, the increase in housing and transport supply create the need for the development and reconstruction of both the street and road network and the city's transport system.

The population mobility within the concept of "smart" implies not only physical availability of personal or public transport and the availability of places in it, but the optimization of a number of "smart" criteria as well:

1) One trip time. The reference value is estimated at 20-40 minutes, taking into account the waiting time. Achieving this value in the modern megalopolis is impossible without "smart" transportation management systems, including both vehicle fleet units themselves and the infrastructure. It is necessary to ensure the integration of automated electronic information systems in the transport flows' management.

Today, traffic flow management is mainly carried out "manually" using information control and video surveillance systems for monitoring traffic intensity. Such methods do not allow solving the problem of reducing the passengers' travel time effectively. The growth of the city's population is constantly increases the burden on the street and road network (Krasnoyarsk is consistently among the ten most dynamically growing cities in Russia with the population of more than 500000 people).

Fundamental importance in this issue is given to the development of information reporting systems about the location of public transport units, which allows the population to plan their time effectively. Today a free Internet service "Your-bus", which allows to determine the location of public transport units (buses), is in operation. There is no possibility to calculate waiting time and travel time along a linked route.
To reduce the travel time of public transport units along the route, there is a dedicated traffic lane on the main traffic arteries (streets with 3 or more lanes in one direction) in the city of Krasnoyarsk, but this is an attempt to solve the problem in a "physical" way, which has the side effect of increasing the time spent on the road for personal transport. Interesting data are contained in the municipal programme "Provision of Passenger Transportation for 2018-2020", suggesting an increase in the speed of public transport for 3 years by $1.97 \%$ only.

2) Transportation security. It is determined both by the quality of public transport units and by the state of the transport infrastructure. According to the municipal statistics for $2016,67.5 \%$ of the public roads in the city of Krasnoyarsk do not meet the standards.

3) Environmentally friendly transportation. Preference should be given to public high-speed transport on electric traction. In fact, the city is dominated by diesel and gas-powered vehicles. There is no high-speed passenger transport. The development of public transport on electric traction is represented by trolleybuses, trams and the city commuter rail and is limited by the geography of the corresponding infrastructure availability, which makes this type of transport not very popular among the city's population.

It is necessary to involve the possibility of building a network of gas filling stations (for the period until 2020), and then - electric vehicle charging stations. This will give an opportunity to increase the share of personal vehicles with high environmental performance.

4) Cost of population mobility. The "smart" concept assumes minimization of all expenses of the population for the city mobility, including financial ones. This indicator is affected not only by the absolute value of the transportation tariff, but also by the possibility of using only one transport unit or the connectedness of routes 
for various categories of public transport. The city of Krasnoyarsk is actively working on this issue, mainly concerning reducing the cost of the population mobility in case of necessity to use several units of transport for one trip.

Possible practical directions of the infrastructure development providing transition to management on the basis of the concept of "smart".

Here, at the first instance, the authors of the article would like to draw attention to the fact that this section does not propose the methods for "smart" development of the city's infrastructure, but only the directions of activities necessary to implement the concept of "smart city" in the future.

Development of transport infrastructure and street and road network, first of all, requires the development of a new concept and design work on the formation of the optimal transport infrastructure of the city, taking into account its characteristics and in accordance with the provisions of the regulatory legal acts of the Government of the Russian Federation.

The development of the transport infrastructure in Krasnoyarsk should include the following activities:

- modernization of the existing transport network: in 2018-2020 it is necessary to carry out the public roads reconstruction, to make them meet the established standards;

- increasing the capacity of the existing transport system in order to reduce travel time and, as a consequence, the amount of exhaust emissions into the atmosphere within the city limits. In the period till 2030 it is necessary to start implementing major investment projects for the construction of new bridge crossings across the Yenisei River, the formation of multi-level round-about traffic interchanges, the reconstruction of the main urban transport highways, the creation and reconstruction of which is provided for by the General Plan of the city of Krasnoyarsk;
- creation of new transport corridors within the territorial boundaries of the city along with the adjacent territories within the framework of the development of the Krasnoyarsk agglomeration regarding its adjacent areas. Formation of regional transport interchange hubs dealing with the internal regional passenger traffic;

- replacement of the vehicle fleet of road transport enterprises with vehicle fleet of a higher economy class, an increase of the share of existing urban electric transport, development of new types of public transport on electric traction in order to improve the ecological state of the urban environment;

- development of a conception and projects for transferring the tank farm and the railway station outside the city limits. Dense urban environment does not allow carrying out large-scale external freight turnover and passenger turnover within the city limits. This event will reduce the burden on the urban transport system;

- creation of new transport infrastructure facilities for the needs of the development of the existing and fundamentally new types of public transport (metro, express tramway, city train, aeroexpress);

- carrying out complex measures to organize the public transport movement in the city of Krasnoyarsk for the allocation of separate lanes for public transport, which will ensure the smooth movement of passenger transport in the busiest sections of the street and road network. This will allow to link the routes at the main interchange points, raise the regularity and the speed of communication, and increase the attractiveness of urban passenger transport.

The implementation of these measures, among other things, is aimed at changing the trend of reduction in demand for transportation services of public transport among the population in favor of private vehicles. 
Development of engineering infrastructure, including the projects for the "smart" networks construction.

The projected growth in the number of population of Krasnoyarsk against the background of the trend of urbanization processes intensification within the Krasnoyarsk agglomeration, an increase in the level of housing and transportation provision for the population and economy diversification will determine the formation of the demand for accelerated development of utilities and development and reconstruction of the street and road network. Infrastructure development of the city within the concept of "smart" should be aimed at the formation of a comfortable living environment that makes it attractive for life.

Directions for infrastructure development of the city of Krasnoyarsk should include:

- Modernization of the existing engineering infrastructure, taking into account environmental requirements based on the concept of the best available technologies (BAT): water disposal and heat supply (development of a project for transition to gas and/or alternative generation). Within the framework of this task, it is necessary to develop and introduce environmental standards (requirements) for the construction and modernization of engineering networks to the municipal management practice (including the municipal order system).

- Development of public transport infrastructure on electric traction (metro, highspeed tramway). Today, almost all new areas of urban development exclude the existence of such an infrastructure. Separately, it is necessary to introduce statistical monitoring of passenger transportation using this type of transport. When designing new areas, consider the possibility of building an infrastructure for high-speed public transport on electric traction (including the land reservation mechanism).
- Development of infrastructure that increases the connectedness of the city with the surrounding territories in the framework of the agglomeration development. It is impossible to implement the infrastructure development of the city within the concept of "smart" only within its boundaries. Under conditions of the current legal system (Federal legislation), it is necessary to develop regional and local documents and plans for joint development of the city.

- Creation of a logistics hub, which could provide effective connections with other cities in Russia and the world. It is necessary to ensure competitiveness with other cities of Siberia and Russia in the number of domestic and international air routes.

In the housing and utilities infrastructure development it is necessary:

- To ensure the use of new durable materials, including through municipal procurement. To reduce the percentage of engineering networks amortization to the normative level.

- Create conditions for the introduction of new resource-saving technologies and integrated automated management systems, including within the framework of the "smart" networks development.

- Improvement of the quality of management based on the growth of the professional competencies of personnel at all levels of decision-making and tasks implementation. The key value to improve the situation in the sphere of housing and utilities services is to increase the professional competence of personnel at all levels of decision-making and tasks implementation. It is necessary to form an effective system of personnel training and retraining: starting a new training programme for personnel 380310: "Housing and Utilities Infrastructure," the expansion of training and the quality of 
training of engineering personnel in the field of engineering networks operation.

- Increase of borrowed funds and private investments in the total amount of investments to the city's engineering development: 2018-2020 not less than $30-35 \%$; $; 2025$ - not less than $40-50 \%$; $2030-50-100 \%$.

The development of the energy infrastructure of the city should be aimed at increasing the environmental friendliness of production and the quality of heat supply to the consumers, increasing economic efficiency through the introduction of energy-saving technologies and gradual abandonment of coal generation. The process of the city gasification can assume two consecutive stages.

Minor gasification (2018-2025) involves:

- gasification of local heat generation facilities due to the transfer of local municipal boiler houses to gas generation or their closure and substitution of their powers by the facilities of the Siberian Generating Company (TPP-1, TPP-2, TPP-3);

- gasification of local boiler equipment installed on several dozen of boiler houses owned by small and medium-sized industrial enterprises that do not have permits and are used with technical irregularities (2018-2020); the remaining solid-fuel boiler plants of industrial facilities are subjected to the transfer to centralized provision or gasification (2016-2025);

- gasification of boiler equipment in lowrise residential buildings - creation of conditions for the replacement of boiler equipment operating on solid fuel components with gas boiler equipment, or transfer to central provision (2018-2025).

Full gasification (after 2025) involves assessment of the economic feasibility of gasification in relation to urban thermal power plants and large industrial facilities; by 2030 it is reasonable to carry out the development of design documentation for the full gasification of the thermal generating capacities of the city of Krasnoyarsk.

Activity areas in the field of developing communication services within the concept of "smart" should include:

- transition to the modern standards of providing communication services;

- expansion of the range of services provided;

- strengthening partnerships with higher education institutions;

- development and implementation of activities aimed at reducing the terms for the coordination of the communication facilities location in the territory of the city;

- technological communication networks improvement.

The market of communication services in Russia as a whole, and in the city of Krasnoyarsk in particular, primarily attracts attention by its growth rates. Communication services occupy one of the most important places in the national economy of Russia, and the growth in the number of subscribers and the ARPU increase is an indicator of the society well-being.

\footnotetext{
A. 1 par. A of the Decree of the President of the Russian Federation No. 600 of 07.05. 2012 "On Measures to Provide the Citizens of Russian Federation with Budget-friendly and Comfortable Housing and Improve the Quality of Housing and Utilities Services".
}

\section{References}

Federal State Statistics Service of the Russian Federation: http://www.gks.ru

The Municipal Programme of the City of Krasnoyarsk "Provision of Passenger Transportation by Public Transport in the City of Krasnoyarsk" for 2018 and the planning period of 2019-2020. 


\section{Умный город. Smart-инфраструктура,}

\section{сети и коммуникации}

М.Б. Двинский, И.А. Дробышев, Н.В. Непомнящая, Т.В. Павлюченко

Сибирский федеральный университет Россия, 660041, Красноярск, пр. Свободный, 79

Современное развитие городов-миллионеров становится все чащуе невозможно «классическим» путем. Ключевая проблема любого динамично растущего мегаполиса - отставание инфраструктурного развития или невозможность последней эффективно удовлетворять потребности всех элементов города. При этом город не имеет возможности предоставить для ее развития новые площади земельных ресурсов. Разные города и страны находят свои решения данного вопроса, в последнее время набирает популярность концепция «smart sity». В статье на примере города Красноярска рассмотрены обязательные требования к инфраструктуре (преимущественно транспортной) в рамках концепции «sтаrt». Определень текущие тренды развития города и сопоставления ожидаемых на практике результатов концепuзии «smart sity», предложены направления развития инфраструктуры города для обеспечения возможности перехода к развитию в концепции «smart». Исследование выполнено в рамках гранта «Методические подходы к формированию концепции создания проекта «Умный город (Smart City)» в контексте трендов развития ичифровой экономики» при финансовой поддержке Красноярского краевого фонда поддержки научной и научно-технической деятельности.

Ключевые слова: smart sity, инфраструктура, транспорт, умные сети.

Научная специальность: 08.00.00 - экономические науки. 